\title{
Addressing Political "Confusion Syndrome” Discourses: A Critical Applied Linguistics Perspective
}

\author{
Joseph Ernest Mambu \\ English Department, Faculty of Language and Literature, \\ Satya Wacana Christian University, \\ Diponegoro 52-60, Salatiga, Central Java, Indonesia \\ e-mail: jos_sala3@yahoo.com
}

\begin{abstract}
This paper aims at extending our understanding of a problematizing practice in Critical Applied Linguistics by exploring issues pertaining to political "confusion syndrome" Discourses. Central to this practice is how EFL teachers and learners depart from their reluctance to explore political issues. Being scaffolded with a working model of such Discourses and a suggested simulation practice, they are hoped to learn how to sympathize with politicians' confusion.
\end{abstract}

Key words: political confusion syndrome Discourses, Critical Applied Linguistics, a problematizing practice, voice

Confusion is pervasive among people around the globe. Much of such confusion is expressed by means of people's verbal and non-verbal expressions. Confusion can be temporary: selecting the best answer in a difficult, multiple-choice test; or choosing whether one should turn right or left in a foreign city. Some confusion brings about lifetime (or at least more permanent) consequences: choosing Lady A or Lady B to be a wife; or applying for job X or job Y. Still other confusion is more subtle but insidious and cultured within a society. Somewhat recently, the former Jakarta Governor Sutiyoso (2002-2007) was taken aback (and I believe some confusion can be implied) when some Australian police almost detained him in Australia for his alleged involvement in a massacre of Australian journalists in Timor Leste in 1975 (Seth, 2007).

It is for this very last example that this paper is devoted: The Discourses of political confusion syndrome. Such confusion syndrome entails someone's capacity involved in political discourses to confuse other people. It also includes the possibility of the people's being confused and making political discourses even more confusing or complicated. The 
observation of confusion here starts from that of the government. Stereotypically, government officials may be confused themselves when challenged by people of their own country or people from foreign countries, and then create confusing statements to the people. While this phenomenon is too pervasive in the world's society, some insights from Critical Applied Linguistics, which is "an approach of teaching similar to that of [critical pedagogy]" (Davies, 1999, p. 145), may shed more light on this taken-for-granted issue. As Pennycook (1994) puts it:

To teach critically implies a particular understanding not only of education in general but also of the critical educator... In order to pursue critical pedagogies of English, then, we need a reconceptualisation of the role for teachers and applied linguists that does away with the theory-practice divided and views teacher/applied linguists as politically engaged critical educators. (p. 303)

What evolves from my discussion is my suggested framework of political confusion syndrome Discourses based on reflections on local or foreign government officials' and politically engaged people's statements or attitudes taken mainly from the mass media. These data, however fragmented, are likely to be studied more systematically in the light of my proposed framework and Critical Applied Linguistics (henceforth CAL) which emphasizes "problematizing practices" (Pennycook, 1999, 2001, 2004, n.d.). A problematizing practice “...gives us a way of working in language education that ... keeps questions of language, discourse, power, and identity to the fore” (Pennycook, 2004, p. 330). Hence, this practice in CAL focuses on how language teachers challenge their own pedagogical approaches that do not address social and political phenomena critically. Uncritical approaches are pervasive in language classes where teachers do not highlight the capacity of languages to contain within them many contesting discourses in which power relations and multiple identities (socially and politically, inter alia) exist. Furthermore, a problematizating practice (or simply "problematization") is "a perspective that insists on casting far more doubt on the categories we employ to understand the social world and on [static] assumptions about awareness, rationality, emancipation, and so forth" (Pennycook, 2004, p. 329). Implied here is the likelihood that even in "critical" language classes, some teachers and students may be trapped in simplistic and static binary oppositions (or 
categories) to promote "democracy" or "equality" (e.g. a "bad" government vs. "marginalized-but-good" people; an "oppressive" school vs. "oppressed" students) - thanks to structuralism, that will only obscure instead of disclosing realities other than such oppositions. It is likely, for instance, that people are not only oppressed by a government but they can also be oppressive to other people and the government alike. By thinking beyond binary oppositions, I position myself more as a poststructuralist (see Barry, 2002 on structuralism and post-structuralism for further details). Post-structuralism is implied in Pennycook's writings which are distinctive from some forms of "more traditional" critical discourse analysis, critical literacy, critical pedagogy, and critical views on language policy (e.g. Pennycook, 2004, p. 329), all of which belong to structuralism and presume that a monolithic entity (e.g. government) accounts for the culprit toward humanity and another entity (e.g. the people or non-government officials) is (relatively) innocent and thus needs "liberation" from the oppressive entity. Other nuanced meanings of problematization will be addressed more elaborately in due course.

\section{TOWARD A MODEL OF POLITICAL "CONFUSION SYN- DROME” DISCOURSES}

Though some EFL teachers may express their reluctance to political issues, I contend that EFL teachers at senior high school or university level need to be politically engaged critical educators. This is in line with the spirit of Critical Pedagogies, that is, pedagogies that aim at "[considering] how, in diverse sites of language education, practices might be modified, changed, developed, or abandoned in efforts to support learners, learning, and social change" (Norton \& Toohey, 2004, p. 2). The site of language education in this article is limited to teaching and learning EFL in Indonesia. The practices here refer to that of presenting language learning materials that contain political issues with the purpose of enhancing learners' capacity to view such issues critically. Social change may occur at least at conceptual level, i.e. through critical reflection. (Actions to bring about social change through demonstration or revolution, nonetheless, are beyond the scope of my discussion here). The modification and development of such materials means political issues need not only be discussed superficially (as is the case in, for instance, the Newspaper Reading course in the English Department of Satya Wacana Christian 
University, Central Java, Indonesia) but they need to have a clear framework with which political voices of people and government officials are critically analyzed.

The stages of analysis EFL teachers can utilize in their classroom evolve from presenting facts and people's opinions of a certain political (and social issue) that can be excerpted from the media. EFL teachers can start with presenting people's (or personal) opinions and facts of a certain political (and social) issue that can be implied and excerpted from the media. To illustrate, as an EFL teacher myself, I may begin with these hypothetical statements conveyed to my students: "If I were an Indonesian government official who were committed to truth and dedication to the people, I would be likely to encounter confusion in making decisions. Certain decisions would benefit some people but disadvantage others. In fact, pros and cons emerge as a policy is issued.” After that I will supply facts to my students. The former Governor of Jakarta, Sutiyoso, for example, has been full enough to reap criticisms concerning his policies which are rarely uncontroversial. Transjakarta (bus way) attracts both proponents and opponents alike in airing their voices. On TV last January 2007 it was shown that some drivers of other public vehicles complained that the bus way only created more traffic jams and at the same time it may cut off their revenues. I do not know what other voices are, which are yet to be included here.

Interestingly, Governor Sutiyoso stated in an article in Kompas, a leading Indonesian newspaper, "Do not merely scold at me. If I only want to play safe, I can choose not to do anything” ("Bus way Jakarta" ["Jakarta Bus way"], 2007). This may be his self-defense mechanism.

In my opinion, the issue may not be what Sutiyoso claims. What seems to be missing is true dialogs in which deliberations of his idea should have undergone the process of being antithetically challenged by Jakarta people. Such challenges do not necessarily mute nor fail his attempts to improve transportation system in Jakarta. Nevertheless, Sutiyoso should have accommodated any possible "weaknesses" and "threats" of bus way from the SWOT analysis framework - that are brought up by Jakarta people, in particular, and address these people's objections.

I doubt Sutiyoso has wisely addressed possible complaints from drivers of angkot or ojek (public transportation in Indonesia), let alone other street users who feel that some streets are now getting narrower whereas the bus way can go through a relatively wide route at ease. 
Some proponents of bus way will agree with Sutiyoso that bus way solves the problem of traffic jams and they will also promote that people change their habits of driving their own individual cars to riding on bus ways. It is a good proposition by Sutiyoso that "Jakarta can only add streets less than one percent whereas the number of vehicles increases by $11 \%$ and thus total traffic jams will definitely take place if we do not prepare mass transportation" (from the same Kompas article). Nonetheless, by saying this, Sutiyoso is at the risk of silencing voices of Jakarta people who are under, if not unrepresented, like angkot and ojek drivers. Another interpretation is that Sutiyoso may have been confused himself but to avoid the impression of being "NATO" (No Action Talk Only), he may have issued and carried out his policies for the sake of implementing his policies, exhibiting his authority, which probably conceals his confusion to address the people's protests.

The snapshot of bus way issue is but a tiny problem from which possible government's silencing voices due to their confusion is created. There are surely other complex matters that reflect political (especially the government's) "confusion syndrome”. Prior to discussing the Discourses of such syndrome, let me make a detour by sharing what I learnt from Gee (2005) recently in his Introduction to Discourse Analysis: Theory and Method ( $2^{\text {nd }}$ edition). He distinguished between Discourses with a capital " $\mathrm{D}$ " and discourses with a small "d". The latter is more at micro level in that it is usually represented in people's utterances in daily conversations, and is inclusive of both verbal and non-verbal expressions. Common exchanges of information such as telephone conversation, saying grace before having meals, small talks as a means of opening a more serious talk with strangers, chatting with colleagues during break time may be considered 'discourses' with this sense. In short, as Gee (2005) submits: "I will reserve the word 'discourse', with a little'd', to mean language-in-use or stretches of language (like conversations or stories)” (p. 26).

Though Discourse (with a capital "D") cannot at times be separated from our daily lives, it is more subtly complex. It may also be (un) intentionally or (un) consciously embedded within day to day conversation as it involves people's worldviews (including the plurality of philosophies, religious or moral values, and ideologies) which are expressed verbally (e.g. written and/or spoken words) or non-verbally (e.g. gestures, facial expressions, etcetera.). As Gee (2005) puts it, 
“Big D” Discourses are always language plus “other [non-language] stuff" [to enact specific identities and activities]. ... If you put language, action, interaction, values, beliefs, symbols, objects, tools, and places together in such a way that others recognize you as a particular type of who (identity) engaged in a particular type of what (activity), here-and-now, then you have pulled off a Discourse (and thereby continued it through history...) (pp. 7, 26-27)

Accordingly, at stake here are political identities and activities as shown by politicians' statements, and EFL teachers and students who probe into critical analysis of these politicians' stances. These stances can be traced through textual history (e.g. the history of bus way in Jakarta, with Sutiyoso as one of the main figures, as historically recorded in the media). Texts (e.g. again, on bus way) within a certain period of time are full of patchworks of political voices. As Gee (2005) contends: "All life for all of us is just a patchwork of thoughts, words, objects, events, actions, and interactions in Discourses” (p. 7).

Space does not permit me to discuss extensively how a piece of language like speech in a text is inherently related to other pieces within or across texts (i.e. "intertextuality") is relevant to textual history and salient patchworks of voices in Discourses (for further explanation on intertextuality see Gee, 2005, pp. 46-48; and Tannen, 2007, pp. 8-24, among others). Suffice it to say here that an intertextual analysis allows researchers and language teachers to find texts that are clustered into themes (e.g. subway, the Indonesian former president Soeharto's demise, etcetera).

Furthermore, the complexity of deciphering the essence of Discourses is arguably more apparent because of the non-verbal factor. Frequently, what is not verbally stated is like the rest of an iceberg that does not appear on the water surface. While analyzing verbal words are difficult already, analyzing gaps (silences) not expressed in such words can be an elusive endeavor. Such an attempt may be made relevant in analyzing government's Discourses if we pay attention to taken-for-granted, common patterns that can be observed based on empirical evidence such as Sutiyoso's controversial decision on bus way briefly discussed earlier.

Going back to the thread of my developing thesis on "Confusion Syndrome Discourses", discoursally, government's verbal statements or non-verbal behaviors in Discourses like their "ways of acting, interacting, 
feeling, believing, valuing...” (Gee, 2005, p. 7) can be predicted as in Figure 1.
(1) Confused him/herself
(2) Calling for other or proponents' voices $\rightarrow$ insistence on own's voice
(3) Silencing opponents $\rightarrow$ not addressing the voices of his opponents

Figure 1. The pattern of politician's confusion syndrome Discourses

This sequence may repeat continuously, forming a vicious cycle. Nonetheless, the real phenomena are likely to be not as clear-cut as the sequence. Hence, stages (1), (2) and (3) may be interchangeable and overlapping. For the sake of discussion (perhaps a bit of oversimplification), the above sequence is proposed. Accordingly, being confused (stage 1) may be indicated by inconsistent statements by a politician (see the example after Figure 3 of Al Gore who was both an anti- and a proabortion). Stage (2) occurs when a politician summons the voices of others (e.g. the percentages that Sutiyoso embeds are supposedly generated from researchers: "Jakarta can only add streets less than one percent whereas the amount of vehicles increases by $11 \%$...”) or his/her proponents (e.g. see the voice of Al Gore's media advisor below Figure 3) to enable him/her to insist on his/her own decision(s). Stage (3) is apparent when a politician is not adequately addressing people's or his/her opponents voices/concerns (e.g. Sutiyoso's reaction "I can choose not to do anything", and in fact he chose to do something - that is going for bus way, has potentially silenced people's objections). Of course prior to making decisions about bus way and stating "If only I want to play safe", he could have dialogued with people like angkot and ojek drivers who will be disadvantaged from his policy.

Captured in the three stages are political Discourses at work, borrowing Gee's (2005, p. 7) formulation: ways of acting for a politician's own interest (and thus against other people's interests), interacting (e.g. among politicians themselves or between politicians and the people in polemics), feeling (of confusion, for instance), believing in and valuing certain ways to support his/her own voice and silence others' voices. 
Furthermore, politics does not only involve politicians or government officials. In fact, non-politicians are capable of producing political statements and hence officials and non-officials alike complicate the Confusion Syndrome Discourses in politics. EFL teachers need to be more aware of this. In the following section, I will discuss how CAL sheds more light on these Discourses.

\section{A MORE SYSTEMATIC METHODOLOGY OF ANALYZING POLITICAL CONFUSION SYNDROME DISCOURSES: INSIGHTS FROM CRITICAL APPLIED LINGUISTICS}

An applied linguistic approach is the entry point here. Applied Linguistics has been broadly defined as "a practice-driven discipline that addresses language-based problems in real-world contexts" (Grabe, 2002, p. 10). With the spirit of CAL, i.e. the problematizing practices which entails being self-critical or self-reflexive (cf. Pennycook, 1999, 2001, 2004), among others, many Indonesian EFL teachers must criticize their own reluctance of dealing with political issues with students. In fact, political discourses are pregnant with language problems and are situated in real-world contexts such as in the media and in daily conversations when people embed political stances in their Discourses. And those who are already accustomed to bringing up such issues in classrooms, need to problematize the taken-for-granted approach such as harshly discrediting politicians from a certain affiliation or party without providing a balanced proportion of voices (or perspectives) from other politicians or people's points of view. Even when in advanced EFL reading courses the identification of biases in the media is relatively prevalent already, this bias identification is still subject to problematization. That is, they are lacking in a more complex framework by which a variety of voices and phases of confusion syndrome Discourses, among others, can be more systematically analyzed. Being systematic here does not mean that the working model I am proposing here (cf. Figures 1 and 3) is static and irrefutable. As Pennycook (n.d.) suggests,

[CAL] is not concerned with producing itself as a new orthodoxy, with prescribing new models and procedures for doing applied linguistics. Rather it is concerned with raising a host of new and difficult questions about knowledge, politics and ethics. (p. 23) 
The new and difficult questions, nonetheless, will be too vague if there is no working model. This implies a problem of Pennycook's own insistence on not prescribing any model or his "anti-disciplinary stance" to "take up a position against the construction of coherence" (p. 24). In essence, the aim of my suggested framework is, in line with Pennycook's, "engagement with difference” (p. 19). That is, people's different voices account for confusion syndrome Discourses: the confusion within oneself (a politician or government official, in particular) is perceived as confusing or conflicting ideas by other people, which in turn produces ever-increasing confusion in a society when more than one person interprets the initial confusion in potentially confusing ways. Once the degree of confusion is multiplied, novel and complex questions concerning politics vis-à-vis language use will require my present model to be deconstructed (i.e. problematized) and I will not have hard feelings for that so long as my aim to engage with difference at this stage is concerned.

The focus of analysis of this engagement is "discursive mapping" (Pennycook, n.d., p. 20). From my understanding, to map means to make sense of the seemingly incoherent realities. This leads me to refute Pennycook who is against the construction of coherence. My compromising stance is that while I may to some extent build up coherence of political confusion syndrome Discourse in a model, I agree with Pennycook who suggests that critical applied linguists need to be aware of their limits of knowing. Despite the limits, in order that CAL is more down-to-earth to EFL pedagogy in Indonesia, I propose a working model (the "discursive mapping") with these purposes. First, it is to engage teachers and students with difference. That is, they need to acknowledge that language teaching and learning does not exist in social vacuum and hence different voices that contribute to confusion syndrome Discourses should be addressed. By so doing, it is hoped that both teachers and students learn to suspend judgment to politicians. Teachers and students may critique politicians' language use but at least by being engaged with difference (e.g. putting oneself in someone's shoes), they become more aware of the complexity politicians have to deal with, e.g. conflicts of interests, clashes of worldviews, and ignorance about a certain law that leads them to produce regulations that are not only against the law but make people confused.

Let me now begin explaining my working model. One preliminary way to address the problems in real-world context here, the political 
"confusion syndrome" Discourses, within the spirit of CAL, is by analyzing voices in language reports as studied by Thompson (1996) in his extensive analyses of written discourse of newspapers. In view of his framework it becomes more feasible to see to what extent a politician (including a bureaucrat or a government official) is more in favor of his own interests, his own parties' interests, or shows his/her empathy to the people. He suggests five sources of voice(s):

Voice(s) of self. This kind of voice may reflect a politician's own (or claimed to be own) voice (e.g. Sutiyoso's statement: “...traffic jams will definitely take place if we do not prepare mass transportation”). Though he used "we" in his utterance, it can be his own assertion or that of unidentified people on the same wave length with him.

Voice(s) of specified other(s). This refers to another speaker's voice "at another time in another place” (Thompson, 1996, p. 508). In politics, voices represented show how favorably or maliciously a politician is with the characters (who are in favor of or against him/her) mentioned in his/her utterances, e.g. the voice of $\mathrm{Al}$ Gore's media advisor which suggested that he evaded from a tough question (see the quoted speech below Figure 3). The voice of his advisor is in favor of his interest to win the presidential election but it is contradictory with his identity as a senator who repudiates abortion (Clayman, 2001). This, I believe, leads to his own and the American people's confusion.

Voice(s) of unspecified other(s). This source may address this question: Are there any possible voices intentionally hidden by bureaucrats? Linguistically, this kind of voice denotes "something as report without specifying the source although the source is, in principle, identifiable" (Thompson, 1996, p. 508), e.g. It was claimed that the platypus laid egg. In the example, the agent (the doer that claims such a proposition) is obscured. Politically, this phenomenon usually occurs when a certain agent is deliberately hidden unless people are more critically aware of this trick. Recall Sutiyoso's statement again: "Jakarta can only add streets less than one percent whereas the amount of vehicles increases by $11 \%$...”. The source of the statistics is not clearly cited. It may be impossible for Sutiyoso himself to come up with such numbers. His expert assistant is likely to report the percentages to him. At worst he made up the numbers, making it his own voice (the voice of self), to sound more scientific and convince the people. Or, if he did not cheat, he subsumed the agency of the statistician under his authorial voice. 
Voice(s) of unspecifiable other. e.g. rhetorical question (All across the country, people spent the rush hour in bed. Some took their wives out to lunch [...] Pick up the kids from school? Certainly). The main reason for concealing the source is that an audience is "encouraged to accept [the voice] as his [or her] own voice" which is more effective and less contestable than saying "No doubt, like many people, you offered to pick the kids up from school” (Thompson, 1996, pp. 510-511). In asking the rhetorical question, the speaker calls for more involvement from his/her audience. Arguably, this anticipatory strategy by a speaker may indicate his/her craftiness in taking into account what the audience may think, want, or reject. In terms of politics, raising rhetorical questions can mean at least three things. First, a bureaucrat shows sympathy or empathy to the people. Second, the question calls for an audience's adherence to a politician's view. Third, a politician evokes the voice of those who question his/her stance. For instance, a rhetorical question - a more complete text is in Tannen (2007) - was raised by Reverend Jesse Jackson in his political speech supporting Michael Dukakis, a president candidate from the Democratic Party, at the 1988 Democratic National Convention:

\author{
Dr. King [Martin Luther King, Jr.] didn’t have the most votes \\ about the Vietnam War, \\ but he was morally right, \\ If we're PRINCIPLED FIRST, \\ our politics will fall into place. \\ “Jesse, why did you take these big bold initiatives.” (p. 172)
}

The confusion here is not very much of Rev. Jess Jackson although it was possible that he had been confused to address the doubt cast by some American people (either democrats, republicans, or non-partisans) when he was preparing his speech. Rather, the imaginary dialog in the form of a rhetorical question "Jesse, why did you take these big bold initiatives [?]" was embedded not only for showing his dazzling display of oratory but also for implying that he took into account some American people's doubts and confusions concerning his involvement in politics. The confused people gathered (either intentionally or coincidentally) to raise their voice to challenge or even silence and dampen Jesse's spirit as a political pastor. These people's silencing capacity, in fact, may also be regarded as 
representing the "voice of a community", the fifth source of voice in Thompson's (1996, p. 509) framework.

Voice(s) of community. e.g. a proverb (The only rescuable items were a heavy rosewood desk... Beggars can't be choosers). Such a proverb is shared among a society so the speaker (or writer) and the audience (hearer or reader) know that the words have been commonly applied within a community. The scope of community may even be narrower, e.g. words frequently used in a family may not be understood by other people outside the family (Thompson, 1996, p. 509). In political realms, the voice of community indicates to what extent a government official holds a certain school of thought/worldview that determines the way he speaks, acts, and raise his/her voice of self. For example, for Christianity-inspired politicians, Romans 13:1-2 ("Everyone must submit himself to the governing authorities, for there is no authority except that which God has established. Consequently, he who rebels against the authority is rebelling against what God has instituted, and those who do so will bring judgment on themselves"; New International Version), may be the guidance to their political worldview. Nevertheless, this verse may be abused by those belonging to absolute power or those communities who maintain the status quo (presumably the middle class or conservative Christians who simply want to play safe). Recall how George W. Bush claimed himself as God's representative, which is supported by some conservative Christians in the U.S.A., so as to justify the war with Iraq (cf. Saraceni's [2003] comments "based on a corpus of Iraq-related Blairisms and Bushisms", p. 3). Later, interestingly, some inconsistencies as to whether he regrets or remains certain with his decision to maintain American troops in Iraq (thus showing his confusion no matter how hard he has tried to conceal it) become apparent.

A photograph of a banner that I took last 26 January 2008 on Diponegoro street Salatiga, Central Java-Indonesia, near Satya Wacana Christian University campus, will enhance Thompson's (1996) notion of voice of community. Represented in the picture is, based on my best guess (as the source remains mysterious), the voice of a community of nongovernment officials (see Figure 2). 


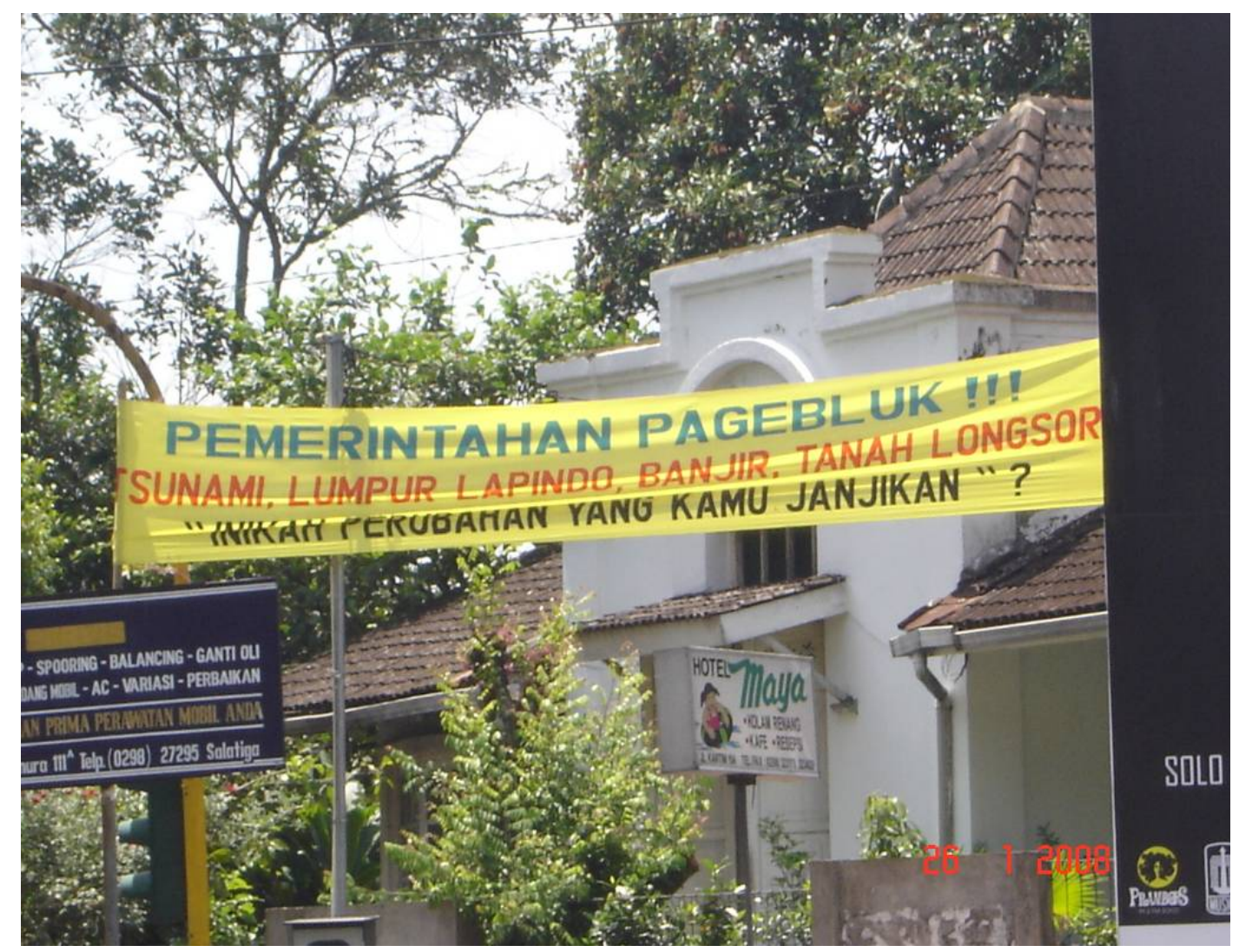

Figure 2. A political voice of the community of government opponents in Salatiga early 2008.

The banner reads: "PEMERINTAHAN PAGEBLUK!!! TSUNAMI, LUMPUR LAPINDO, BANJIR, TANAH LONGSOR - 'INIKAH PERUBAHAN YANG KAMU JANJIKAN?' (THE GOVERNMENT BRINGS ABOUT [or plagues the people with] DISASTERS!!! TSUNAMIS, 'LAPINDO' ERUPTIVE HOT MUD [in Sidoarjo, East Java], FLOODS, LANDSLIDES - 'ARE THEY CHANGES YOU PROMISE?'). This provocative banner shows a very harsh Discourse (criticism) toward the ruling government. Despite being critical, the banner shows political "confusion syndrome" Discourses. First, some people are so confused and frustrated - as to how they are stricken by continuous calamities, that they are trapped in a serious logical fallacy. To illustrate, there have been disasters since 2004; Susilo Bambang Yudhoyono (SBY) has become the Indonesian president since 2004; SBY and the state apparatus have caused the disasters. Second, being confused, these people call for (if not incite) the society to condemn the present government. Third, by being judgmental in confusion and frustration, these people 
(in)directly silence the government officials who are incapable of creating or handle enormous natural disasters. In fact, these officials themselves may also have been really confused by the disasters. In my opinion, the political content in the banner is counter-productive in that it only makes the government more confused.

Methodologically, sources of voices can be traced in photographs (see Figure 2) or by concordancing tools. The latter can be done in at least two approaches. First, we compile a corpus of newspaper reports (from several newspapers) and TV coverage (from several TV stations) on individual topics (e.g. bus way in Jakarta, Adam Air accident on 1 January 2007) and focus our attention to government officials statements, people's voices, and reporters' comments and then we see how the government respond to people's voices. Second, we direct our attention towards several issues that still belong to one cluster of topic, e.g. recent accidents in January 2007 (Adam Air, Senopati Nusantara ship, train "Bengawan", Indonesian teachers' certification, etcetera.). The time scope for compiling corpora of both approaches can be determined by a researcher, e.g. a corpus of bus way issue in Jakarta from January to December 2007 compiled from editorials, letters to the editor, and headlines in Kompas and The Jakarta Post, and transcribed TV talk shows.

Now, let's recall my initial framework, as formulated in Figure 1: (1) confused him/herself $\rightarrow$ (2) insistence on own's decision $\rightarrow$ (3) silencing opponents. This initial model is to be synthesized with Thompson's (1996). In view of his five sources of voices, any indication of political (government officials') confusion in each stage of my framework can be traced when selected news coverage from our corpora of transcribed TV news, newspapers, and magazines are scrutinized (see Figure 3).

With regards to government officials' voices, we can derive the data directly from interviews with them (e.g. in TV talk shows). A relevant example to this, that may also exhibit the first stage of a politician's confusion syndrome (confused him-/herself), is when Al Gore was bitterly divided over his own status as a U.S. senator who is opposed to most types of abortion and as a Clinton's presidential campaign supporter who has to compromise his stance by supporting Clinton's health care reform plan that is pro abortion. It was reported that in an interview on TV, Gore attempted hard to evade from answering Sam Donaldson's (the interviewer's) tough questions regarding abortion. Once his media advisor even recommended Gore to evade such a question: “Don't be afraid to turn their questions. 


\begin{tabular}{|c|c|c|c|}
\hline $\begin{array}{r}\text { Confusion } \\
\text { phenomena }\end{array}$ & Confused him-/herself & $\begin{array}{c}\text { Summoning } \\
\text { proponents' voices }\end{array}$ & $\begin{array}{c}\text { Silencing } \\
\text { opponents' voices }\end{array}$ \\
\hline Sources of voices & $\begin{array}{r}\begin{array}{c}\text { Data for filling in the gr } \\
\text { interviews, talk shows, } \\
\text { banners, amon }\end{array} \\
\end{array}$ & $\begin{array}{l}\text { ids below can be elicite } \\
\text { magazines, newspapers } \\
\text { ag others, in a certain pe }\end{array}$ & $\begin{array}{l}\text { srom corpora of TV } \\
\text { s, and photographs of } \\
\text { aiod of time. }\end{array}$ \\
\hline Voice of self & $\begin{array}{l}\text { Al Gore's ambivalence } \\
\text { stances: pro and anti } \\
\text { abortion; Sutiyoso's } \\
\text { implied confusion when } \\
\text { he was almost detained } \\
\text { in Australia. }\end{array}$ & & $\begin{array}{l}\text { Sutiyoso's statement: } \\
\text { “Do not merely scold } \\
\text { at me. If I only want } \\
\text { to play safe, I can } \\
\text { choose not to do } \\
\text { anything”. }\end{array}$ \\
\hline $\begin{array}{l}\text { Voice of identified } \\
\text { others }\end{array}$ & & $\begin{array}{l}\text { The voice of Al Gore's } \\
\text { media advisor for Al } \\
\text { Gore to evade a tough } \\
\text { question. }\end{array}$ & \\
\hline $\begin{array}{l}\text { Voice of unidentified } \\
\text { others }\end{array}$ & \begin{tabular}{|l|} 
Addressing those \\
unidentified who \\
opposed to his decision \\
on busway, Sutiyoso \\
exerted his self-defense \\
mechanism: "Do not \\
merely scold at me..."
\end{tabular} & $\begin{array}{l}\text { Sutiyoso’s statement: } \\
\text { “Jakarta can only add } \\
\text { streets less than one } \\
\text { percent whereas the } \\
\text { amount of vehicles } \\
\text { increases by } 11 \% . . . ”\end{array}$ & \\
\hline $\begin{array}{l}\text { Voice of unspecifiable } \\
\text { others }\end{array}$ & $\begin{array}{l}\text { American people who } \\
\text { were confused by Jesse } \\
\text { Jackson's political } \\
\text { stance. } \\
\end{array}$ & $\begin{array}{l}\text { An intentionally or } \\
\text { coincidentally } \\
\text { summoned voice of } \\
\text { some Americans who } \\
\text { were confused by } \\
\text { Jesse. }\end{array}$ & $\begin{array}{l}\text { Some Americans’ } \\
\text { “voice silencing } \\
\text { capacity” toward } \\
\text { Jesse. }\end{array}$ \\
\hline Voice of community & \begin{tabular}{|l} 
Communities of pro- \\
and anti- abortion fell Al \\
Gore apart; see also the \\
street banner in Figure \\
2.
\end{tabular} & $\begin{array}{l}\text { The voice of } \\
\text { Fundamental Christian } \\
\text { community in George } \\
\text { W. Bush's political } \\
\text { statements on war } \\
\text { against Iraq; see also } \\
\text { the street banner in } \\
\text { Figure 2. }\end{array}$ & $\begin{array}{l}\text { Voices of the } \\
\text { community of ojek } \\
\text { and angkot drivers as } \\
\text { shown on TV do not } \\
\text { seem to be listened to } \\
\text { by Sutiyoso; see also } \\
\text { the street banner in } \\
\text { Figure } 2 \text {. }\end{array}$ \\
\hline
\end{tabular}

Figure 3. A tentative framework to analyze political "confusion syndrome” Discourse with some fragmented examples from various political issues.

If they ask you about [abortion], just say... 'I want to talk today about the new direction that Governor Clinton and I want to take the country." (Clayman, 2001, p. 403). Knowing such conflicts of interest, our language learners can learn to be critical without being too harshly judgmental to 
politicians. Learners can be directed to understanding different identities politicians, or even the learners themselves, have that account for ambivalent attitudes toward an issue like abortion. Such doublemindedness (or, simply said, confusion) can be a news commodity by the media. Concerning the framework in Figure 3, Al Gore's voices belong to the voices of self (as both an anti- and a pro-abortionist) and the voice of identified other which is that of the media advisor.

In fact, the voices of government officials can be distorted or endorsed by media reporters as well. To a great or less extent these voices can be biased by the media. Therefore, language learners need to be aware of the strategies used by media reporters who expose highly controversial issues. These reporters potentially direct the audience toward a certain political stance and the audience who initially support a certain politician may end up being confused, changing their minds and supporting another politician.

The United States has had politicians who shared fraudulent testimonies in the media, especially during political campaigns, concerning their allegedly immoral conducts. One of the strategies used by media reporters to pin down the politician untruthfulness is by virtue of "embedded metapragmatics". This strategy enables a TV reporter, in this case talking to an anchor of the newscast, to embed someone's claim toward someone else embedded in the reporter's utterance, without the reporter assuming responsibility of uttering the allegation. For example, a reporter may say, "Bush claimed that Clinton lied" (Wortham \& Locher, 1999, p. 109). By saying this statement, the reporter creates a doublevoiced utterance (cf. Bakhtin, 1981) in which both Bush's and Clinton's voices and their connection to each other come to the fore. This utterance also implies the reporter's discrediting Clinton. In view of Thompson (1996), the notion of embedded metapragmatics can enrich our understanding through further investigation of how not only media reporters but also politicians (government officials) themselves may derive double voices from others to speak in favor of or against the people or their political enemies.

To complicate the framework as proposed in Figure 3 is the necessity of collecting data from sources, other than the government themselves and media people, that represent both opposing and supporting views, i.e. from lay people and local (and/or foreign) scholars/experts (such as political observers). These can be elicited by way of questionnaires, recorded interviews (personally with the officials or transcribed from talk shows or parodies on TV), and letters to the editor. These await further attention. 
In essence, the complicatedness of taking into account people's voices besides the voices orchestration by the government officials cannot be abandoned in our analyses. That is, it is impossible that the government become confused solely on the grounds that they have conflicts of interests just as the example of $\mathrm{Al}$ Gore explained above. It is likely that they are often made confused by contesting voices that their people raise to them: (1) strongly agreeing with; or (2) moderately conforming to; or (3) being doubtful about (or abstain); or (4) slightly disagreeing with; or (5) vehemently opposing to the government's policies (cf. Figure 2 above), with each voice having nuanced reasons for their attitudes toward the government. Thus, the modernist (structuralist) binary oppositions commonly espoused in some traditional interpretations of critical approaches such as that of Freire and Critical Discourse Analysis which presuppose and divide the society only into a dichotomous relation between oppressors and the oppressed, with the latter normatively having to blatantly expose the discourses and discursive tools of the former (cf. some critiques toward critical approaches including Critical Pedagogy in Davies (1999) and Pennycook (1999, 2001, 2004), can be as much as possible avoided. This critique is what Freire (1970) has actually envisaged and somewhat addressed: the oppressed can end up being the oppressor themselves; that is, the people regardless of their unfavorable marginalization due to government's policies, can oppress the government by, for example, inelegant curses and violence in demonstrations.

Furthermore, in line with Pennycook's (1999) call for a problematizing practice, EFL teachers and learners need to problematize the "givens", even insights from Critical Pedagogy that may run the risk of totalitarianism of "normative leftist politics" and misleading romanticism of people's “empowerment” or “emancipation” (pp. 334, 343). As he further suggests, "[a] critical approach that claims only to emancipate people through a greater awareness of their condition is both arrogant and doomed to failure" (p. 343). Hence, with regards to political confusion syndrome Discourse, it is inadequate to position the government as the only perpetrator of all evils.

Being more aware of the government's confusion is essential. Nevertheless, it is but a preliminary step in a problematizing practice. We need to push our thinking beyond "pessimistic, deterministic, and reproductive" critical analyses which "tend to suggest that people are trapped in unequal relations of power (e.g. ... the power of English goes on 
increasing, racism has always been and will always be part of human life)" (p. 335). Thus, whether it be "transforming" the society or not, a less illdefined (cf. Davies's (1999) skepticism on CAL), and yet still complex, approach is by utilizing my proposed framework (cf. Figure 3) to take into account not only the government's voices but also the laypeople's and the media's voices or biases. In fact, the framework in Figure 3 can also be used to analyze confusion syndrome of the opposing parties which criticize the ruling party (i.e. the government). By so doing, we give some room for self-criticism, which is useful in at least two ways. First, voices of the people (e.g. non-governmental organizations, the opposition, media, and laypeople) may account for the government's confusion syndrome. Second, being self-critical paves the way for owning empathy toward the "Othered" which are not necessarily those labeled as the "marginalized" or "oppressed" people (Luke, 2004, p. 27). In fact, the so-called "oppressors" like government officials can be made as the Othered (oppressed) by harsh, judgmental, and biased oppositions. Simply put, with empathy as a nongovernment official I can ask this: "If I were a government official myself, what would I do/say/react in a confusing situation?” Sophisticatedly put, empathy may also "[entail] an epistemological Othering and 'doubling' of the world - a sense of being beside oneself or outside of oneself in another epistemological, discourse, and political space than one typically would inhabit” (Luke, 2004, p. 26).

In the light of Figures 1 and 2, not only government officials but also people in general are likely to be confused themselves, summon likeminded voices, and silence opponents' voices. More empirical evidence is necessary not only to fill in blank slots in Figure 3 but also to confirm or falsify (problematize) my tentative model. More plausible interpretations based on or apart from this framework are more than welcome.

\section{FUTURE OUTLOOKS}

In terms of further research, a quantitative analysis may be elusive as sources of voices and confusion phenomena can be overlapping. It is not impossible though that percentages that show a relative prevalence of a source of voice embedded in, let's say, a governor's discourse, in comparison to another source of voice may indicate the preferred strategies the governor employs to conceal his confusion, to summon proponents' voices, or to silence opponents' voices. But still, it is very difficult and only intrigues ardent researchers. 
A qualitative inquiry is hardly less challenging but more pedagogically promising. That is, both EFL teachers and students, as collaborative inquirers, can explore the taken-for-granted, universal phenomenon of ambiguity or confusion derived from political statements (by government, lay people, or people in media) in a number of ways. First, teachers and learners are linguistic inquirers when they analyze sources of voices: exploring sentence structures of "direct" and "reported" speech (or currently termed as "constructed dialogue" by Tannen, 2007, p. 112, who is against the idea that a speech is naively reported verbatim, if at all possible, by a speaker without alteration of intention from the original speech quoted), passive voice, Wortham and Locher's (1999) notion of embedded metapragmatics, specific verbs for reporting, among others. Second, they raise awareness of possible non-verbal and verbal confusion phenomena as shown on TV and printed on other electronic media. The first two ways are the direct application of my model in Figure 3. Third, they enhance empathy by embodying certain roles during classroom sessions.

For example, class is divided into several groups. In the first session, each group is to read political statements of a represented role assigned by teacher. These statements revolve around a particular topic (e.g. teacher certification in Indonesia) and are to be found in newspaper articles or transcribed TV interviews selected by the teacher from his/her corpora which are compiled in the past four weeks, for example. During silent reading, these students have to find relevant statements for their group role. One group represents government officials; another group becomes journalists; and still another personifies lay people protesting the government's policy via letters to the editor. In the second session, each group is to perform (simulate) its role to the rest of the class: by reading or acting out a press conference (for the government group); by orally responding to the government critically during a press conference (for the journalists group) or showing a constructively written letter prior to or after listening issues in the press conference (for the lay people group). They should be inspired by, but not limited to, the texts which are read silently beforehand. Therefore, in their groups, the students may improvise their own statements apart from the reading texts. This session is preferably video-taped. In the third session, the teacher will lead a whole class discussion to revisit issues on political confusion syndrome Discourses. To do this, the teacher will stop at any point during the video tape play when 
he/she or any other members of the class can identify a student or group confusion while they were trying to address the other students' or groups' political statements (cf. stimulated recall procedure by Bailey, 1996, p. 19). By learning how to be confused in this simulation (cf. learning from simulations as a model of teaching in Joyce, Weil, \& Calhoun, 2000), they will hopefully sympathize with the people (especially politicians) whose statements or attitudes are likely to be confusing. They are also challenged to be self-critical so as to minimize confusing statements and behaviors to their potential audience.

By all means, my suggested pedagogical procedure is subject to modification and problematization. At least, however, it has set up an agenda for research that will verify the extent to which teachers and learners develop their problematizing practices in the classroom.

\section{CONCLUSION}

Avoiding myself from constructing "a critical theory of everything" (Pennycook, 1999, p. 345), what I propose here may appeal the academia to approach the ramified phenomena of political confusion syndrome in a variety of contexts and cases by incorporating the matrix that consists of my tentative ideas on three components/stages in confusion syndrome Discourses and Thompson's (1996) notion of sources of voices (see Figure 3 again). With these in mind, I hope EFL teachers can begin to problematize their practices which often avoid social issues in classrooms or merely include such issues by disgracing and condemning the government without offering room for solution or empathy to them. Last but not least, through my tentative procedure of classroom simulation practice, EFL educators and learners will have some experiences to be in political spaces other than what they usually dwell in (cf. Luke, 2004) so they can understand how it feels to be a confused government official who is criticized by the people. They can also be more conscious of the ways (1) a confused official wants to be treated or respected humanely by the people and (2) someone, regardless of his/her profession, can make himself/herself be understood well by minimizing confusing statements.

\section{REFERENCES}

Bailey, K. M. (1996). The best laid plans: teachers' in-class decisions to depart from their lesson pl7ans. In K. M. Bailey \& D. Nunan (Eds.), Vocies from the language classroom (pp. 15-40). Cambridge: Cambridge University Press. 
Bakhtin, M. M. (1981). The dialogic imagination (C. Emerson \& M. Holquist, Trans.). Austin: University of Texas Press.

Barry, P. (2002). Beginning theory: An introduction to literary and cultural theory $\left(2^{\text {nd }}\right.$ ed.). Manchester and New York: Manchester University Press.

Busway Jakarta terpanjang di dunia. [the longest Jakarta bus way in the world]. (2007, January 28). Kompas, p. 1.

Clayman, S. E. (2001). Answers and evasions. Language in Society, 30, 403-442.

Davies, A. (1999). An introduction to applied linguistics: From practice to theory. Edinburgh: Edinburgh University Press.

Freire, P. (1970). Pedagogy of the oppressed (M. B. Ramos, Trans.). New York: Continuum Books. (Original work published 1968).

Gee, J. P. (2005). An introduction to discourse analysis: Theory and method $\left(2^{\text {nd }}\right.$ ed.). New York and London: Routledge.

Grabe, W. (2002). Applied linguistics: An emerging discipline for the 21st century. In R. B. Kaplan (Ed.), The Oxford handbook of applied linguistics (pp. 312). Oxford: Oxford University Press.

Joyce, B., Weil, M., \& Calhoun, E. (2000). Models of teaching (6 $6^{\text {th }}$ ed.). Boston: Allyn and Bacon.

Luke, A. (2004). Two takes on the critical. In B. Norton \& K. Toohey (Eds.), Critical pedagogies and language learning (pp. 21-29). Cambridge: Cambridge University Press.

Norton, B., \& Toohey, K. (2004). Critical pedagogies and language learning: An introduction. In B. Norton \& K. Toohey (Eds.), Critical pedagogies and language learning (pp. 1-17). Cambridge: Cambridge University Press.

Pennycook, A. (1994). Incommensurable discourse. Applied Linguistics, 15(2), 115-138.

Pennycook, A. (1999). Introduction: Critical approaches to TESOL. TESOL Quarterly, 33(3), 329-348.

Pennycook, A. (2001). Critical applied linguistics: A critical introduction. Mahwah NJ: Lawrence Erlbaum Associates.

Pennycook, A. (2004). Critical moments in a TESOL praxicum. In B. Norton \& K. Toohey (Eds.), Critical pedagogies and language learning (pp. 327-345). Cambridge: Cambridge University Press. 
Pennycook, A. (n.d.). Critical applied linguistics. Retrieved 17 August, 2007, from http://www.education.uts.edu.au/ostaff/staff/pennycook_cal.pdf.

Saraceni, M. (2003). The strange case of Dr Blair and Mr Bush: Counting their words to solve a mystery. English Today, 19(3), 3-13.

Seth, S. P. (2007, June 12). Sutiyoso and the angry neighbors. The Jakarta Post. Retrieved March 25, 2008, from http://www.thejakartapost.com/news/2007/ 06/12/sutiyoso-and-angry-neighbors.html.

Tannen, D. (2007). Talking voices: Repetition, dialogue, and imagery in conversational discourse ( $2^{\text {nd }}$ ed.). Cambridge: Cambridge University Press.

Thompson, G. (1996). Voices in the text: Discourse perspectives on language reports. Applied Linguistics, 17(4), 501-530.

Wortham, S., \& Locher, M. (1999). Embedded metapragmatics and lying politicians. Language \& Communication, 19, 109-125. 